DOI 10.4467/2543733XSSB.17.011.7257

\title{
PROBLEM WYCOFANIA RADZIECKICH WOJSK Z NIEMIEC I Z POLSKI W OBRADACH KOMISJI SPRAW ZAGRANICZNYCH SENATU 25 STYCZNIA 1991 R. ${ }^{1}$
}

Słowa kluczowe: Komisja Spraw Zagranicznych Senatu, wojska radzieckie, ewakuacja, tranzyt, Polska, Niemcy, ZSRR

Senat I kadencji, powołany do życia na skutek nowelizacji konstytucji w 1989 r., zajmował szczególną pozycję w ówczesnej strukturze organów władzy państwowej. Nie był drugą izbą parlamentu, ale kolejnym obok sejmu organem przedstawicielskim. Stanowił nowy element $\mathrm{w}$ niezmienionym jeszcze ustroju politycznym ${ }^{2}$.

W trakcie obrad Okrągłego Stołu zamierzano powierzyć Senatowi funkcje kontrolne, szczególnie w zakresie ,praw człowieka i praworządności oraz życia społeczno-gospodarczego". Wprawdzie ta intencja nie znalazła odzwierciedlenia w aktach prawnych, jednak Senat I kadencji wielokrotnie starał się tę rolę spełniać. Marszałek Senatu Andrzej Stelmachowski uważał, że Senat powinien rozważać sprawy o znaczeniu strategicznym, inicjować zmiany typu ustrojowego, kontrolować ustawy i być wyrazicielem opinii publicznej. Senat wykonywał te zadania, między innymi, prowadząc debaty problemowe na tematy ważne z punktu widzenia zainteresowania społecznego i polityki państwa ${ }^{3}$.

Debaty Senatu, które obejmowały również zagadnienia polityki zewnętrznej i spraw międzynarodowych, odbywały się przede wszystkim na posiedzeniach Komisji Spraw Zagranicznych, ale również na posiedzeniach plenarnych. W debatach Komisji Spraw Zagranicznych uczestniczyli nie tylko jej członkowie, ale także zaproszeni goście, a nie-

1 Tekst powstał w ramach realizacji projektu nr $11 \mathrm{H} 13046582$ Dokumenty przełomu. Polska transformacja ustrojowa $w$ latach 1989-1991 w dokumentach Obywatelskiego Klubu Parlamentarnego, Komitetu Obywatelskiego przy przewodniczacym NSZZ ,, Solidarność” oraz Komitetów Obywatelskich „, Solidarność”, kierowanego przez dr hab. Irenę Annę Słodkowską, finansowanego przez Narodowy Program Rozwoju Humanistyki.

${ }^{2}$ Wojciech Orło w s k i, Senat Rzeczpospolitej Polskiej w latach 1989-1991. Geneza Instytucji, Warszawa 2009, s. 66.

3 Ibidem, s. 246-249. 
rzadko przedstawiciele Ministerstwa Spraw Zagranicznych (dalej MSZ). Jako zaplecze merytoryczne Senat powołał zespół ekspertów w postaci Ośrodka Studiów Międzynarodowych Senatu (dalej OSM) ${ }^{4}$.

Jedna z takich debat odbyła się na posiedzeniu Komisji Spraw Zagranicznych Senatu w dniu 25 stycznia 1991 r. po incydencie na granicy polsko-niemieckiej w Olszynie. Dnia 20 stycznia 1991 r. polscy celnicy zatrzymali 220 ciężarówek wojskowego pochodzenia, konwojowanych przez uzbrojonych radzieckich żołnierzy, które udawały się tranzytem z Niemiec do ZSRR. Samochody były pozbawione rejestracji i dowodów ubezpieczenia. Celnicy uznali transport za wojskowy, mimo że oficjalnie ciężarówki wiozły do ZSRR dary niemieckiej Cerkwii prawosławnej. Zatrzymanie konwoju humanitarnego spotkało się z mało przyjaznymi komentarzami w niemieckich i radzieckich mediach, jako wyraz złej woli. Nie bez racji. Konwój został zatrzymany w wyniku impasu, w jakim znalazły się rokowania polsko-radzieckie nad dwoma projektami: traktatu o ewakuacji radzieckich wojsk z Polski i traktatu o tranzycie radzieckich wojsk z Niemiec przez terytorium Polski ${ }^{5}$.

W tej sytuacji Komisja Spraw Zagranicznych Senatu zebrała się, by wysłuchać sprawozdania z przebiegu rokowań ze Związkiem Radzieckim. Posiedzenie, zamknięte dla dziennikarzy, prowadził przewodniczący Stanisław Dembiński. Dyskusja, która wówczas miała miejsce, pozwala zrozumieć taktykę, jaką w rozmowach przyjął polski MSZ oraz towarzyszące jej obawy nie tylko senatorów, ale i członków rządu.

\section{Przebieg polsko-radzieckich rozmów w sprawie ewakuacji wojsk z Polski}

Polska, w porównaniu z Węgrami i Czechosłowacją ${ }^{6}$, najpóźniej rozpoczęła negocjacje w sprawie ewakuacji Północnej Grupy Wojsk Armii Radzieckiej stacjonującej na jej terytorium, mimo że rząd ZSRR okazywał chęć przystąpienia do rozmów w tej sprawie już na początku 1990 r. W dniu 12 lutego 1990 r. radziecka „Prawda” opublikowała Oświadczenie Rządu ZSRR w sprawie gotowości przeprowadzenia rozmów dotyczacych wojsk radzieckich w Polsce, w którym wyrażono wolę podjęcia negocjacji, gdyby Polska wystąpiła z taką propozycją. Stanowisko to potwierdził minister spraw zagranicznych ZSRR Edward Szewardnadze podczas wizyty prezydenta Wojciecha Jaruzelskiego w Moskwie w dniach od 11 do14 kwietnia 1990 r. $^{7}$

4 Ibidem, s. 252.

5 Wysłanie tego konwoju uznano w polskim MSZ za prowokację. J. Makarczyk, odpowiedzialny za negocjacje z Rosjanami, podjął decyzję o jego zablokowaniu. Premier J. K. Bielecki uważał, że wysłanie konwoju było radziecką próbą utworzenia korytarza transportowego przez terytorium Polski drogą faktów dokonanych. Szeroko o tym pisze Joanna S trze lc zy k, Ucieczka ze Wschodu, Rosja w polskiej polityce 1989-1993, Warszawa 2002, s. 144-145.

${ }^{6}$ Czechosłowacja podpisała traktat o ewakuacji wojsk radzieckich w lutym 1990 r., a Węgry w marcu 1990 r. Wycofanie Środkowej Grupy Wojsk Radzieckich z Czechosłowacji zakończyło się 25 czerwca 1991 r., zaś Południowej Grupy Wojsk Radzieckich z Węgier 19 czerwca 1991 r., J. S tr z el c zy k, op. cit., s. 64; na terenie Polski stacjonowało około 50 tys. żołnierzy i 50 tys. osób cywilnych, w tym rodzin, oraz olbrzymie zaplecze techniczne, Krzysztof R o g o w i c z, Rola sejmu w wycofaniu wojsk armii radzieckiej z terytorium Polski, www. lazarski.pl/pl/pobierz/340/, dostęp 25 I 2017, s. 204; A. H a j n i z, Ze soba czy przeciw sobie. Polska-Niemcy 1989-1992, Warszawa 1996, podaje 58 tys. wojsk radzieckich w Polsce, s. 120.

7 J. Strzelczyk, op. cit., s. 67-68, 71-72. 
Jednak rząd Tadeusza Mazowieckiego nie podjął inicjatywy w tej sprawie w pierwszej połowie 1990 roku. Zwłoka była świadomą decyzją, przyjętą po ogłoszeniu 28 listopada 1989 r. przez kanclerza RFN Helmuta Kohla programu zjednoczenia Niemiec, w którym zabrakło odniesienia do ich granic. Rząd Polski rozpoczął starania o potwierdzenie granicy na Odrze i Nysie Łużyckiej przed zjednoczeniem Niemiec. Zabiegając o poparcie ZSRR w tej sprawie, nie chciał podejmować trudnego tematu ewakuacji wojsk radzieckich z Polski, aż do wyjaśnienia kwestii granic. Na konferencji 2+4 w Paryżu 17 lipca 1990 r. Krzysztof Skubiszewski uzyskał stosowne zapewnienia, a 12 września 1990 r. w Traktacie o ostatecznej regulacji $w$ odniesieniu do Niemiec stwierdzono, że wraz ze zjednoczeniem zostaną ostatecznie określone granice, zaś granica wschodnia zostanie potwierdzona wiążącym traktatem ${ }^{8}$. Dopiero wtedy Ministerstwo Spraw Zagranicznych zdecydowało się na kroki zmierzające do zakończenia obecności radzieckiej armii w Polsce.

Sytuację Polski komplikował jednak fakt, że 16 lipca 1990 r. kanclerz Helmut Kohl i Michaił Gorbaczow uzgodnili podpisanie układu o ewakuowaniu radzieckich wojsk z Niemiec. W dniu 9 października $1990 \mathrm{r}$. Niemcy i ZSRR porozumiały się w kwestii konsekwencji finansowych związanych z wycofaniem radzieckich wojsk, natomiast 12 października zawarły traktat o warunkach wycofania wojsk radzieckich z Niemiec. Wreszcie 9 listopada 1990 r. podpisały traktat o dobrym sąsiedztwie, partnerstwie i współpracy. W rezultacie podpisanych porozumień ewakuacja radzieckich wojsk miała się zakończyć w 1994 r. Niemcy zobowiązały się, że udzielą ZSRR pomocy finansowej i wybudują dla powracających żołnierzy radzieckich mieszkania9.

Krzysztof Skubiszewski 7 września 1990 r. zaproponował radzieckiemu ambasadorowi Jurijowi Kaszlewowi podjęcie rozmów w sprawie ewakuacji wojsk radzieckich z Polski, zaś 15 września $1990 \mathrm{r}$. MSZ przedstawiło stronie radzieckiej projekt traktatu ${ }^{10}$. Jerzy Makarczyk, thumacząc 25 stycznia 1991 r. senatorom przyczyny opóźnienia rozmów o wycofaniu armii radzieckiej z Polski, oświadczył: „,najpierw teren się ogradza, a potem sprząta”"11.

Rosjanie długo zwlekali z odpowiedzią. Dopiero 11 października 1990 r. podczas wizyty w ZSRR (10-15 X 1990 r.) Skubiszewski uzgodnił z Szewardnadze, że rozmowy rozpoczną się 15 listopada 1990 r. w Moskwie. Na czele polskiej delegacji stanął podsekretarz stanu w Ministerstwie Spraw Zagranicznych Jerzy Makarczyk, któremu towarzyszyli między innymi: Zdzisław Ostrowski, pełnomocnik rządu do spraw pobytu radzieckich wojsk w Polsce, Grzegorz Kostrzewa-Zorbas, zastępca Dyrektora Departamentu Europy w MSZ, Witold Chodakiewicz, wiceminister transportu oraz Jan Parys, dyrektor generalny w Centralnym Urzędzie Planowania ${ }^{12}$.

${ }^{8}$ J. S tr ze l c zy k, op. cit., s. 55-61, 72; Antoni D u de k, Historia polityczna Polski 1989-2002, Warszawa 2013, s. 70-71; Dieter B ing e n, Niemcy i Polska w nowym porządku europejskim, „Przegląd Zachodni”, 1992, nr 2, s. 29; Kay Hailbronner, Prawne aspekty zjednoczenia dwóch państw niemieckich, „Przegląd Zachodni”, 1991, nr 4, s. 108. Kay Hailbronner wyjaśnia, że dopiero traktat z 12 IX 1990 r., wraz z polsko-niemieckim traktatem granicznym z 14 XI 1990 r., zmieniły niewyjaśnioną sytuację prawną dawnych niemieckich terenów wschodnich, s. 108-109.

${ }_{9}^{9}$ Erhard C zi o m e r, Historia Niemiec wspótczesnych 1945-2005, Warszawa 2006, s. 354-356; K. H a ilbronner, op. cit., s. 106-108.

10 J. S tr ze lc zy k, op. cit., s. 77-76; H. K o h 1, Pragnąem jedności Niemiec, Warszawa 1999, s. 253-254.

${ }^{11}$ Protokół posiedzenia Komisji Spraw Zagranicznych Senatu (dalej Posiedzenie KSZ Senatu) 25 I 1991, Archiwum Senatu 29/22, referat J. Makarczyka, s. 10-11; A. D u dek, op. cit., s. 72.

12 J. Strzelczyk, op. cit., s. 117, 131-132; K. Rog ow ic z, op. cit., s. 204-205. 
Polski projekt układu przewidywał likwidację wszystkich radzieckich placówek wojskowych. W pierwszej kolejności miały się wycofać wojska o charakterze ofensywnym. Nie był to jednak twardy warunek, bo przy znikomej liczbie wojsk radzieckich w Polsce nie miało to takiego znaczenia. Układ zawierał szereg punktów szczegółowych, dotyczących zapewnienia bezpieczeństwa radzieckim żołnierzom i polskiej ludności. Opuszczanie przez radzieckich żołnierzy placówek i domów miało się odbyć na wzajemnie uzgodnionych warunkach. Do układu dołączono protokół dodatkowy, regulujący kwestie finansowe, majątkowe oraz prawne. Polska wprowadziła też zapis, by porozumienie było realizowane od chwili podpisania, bez oczekiwania na ratyfikację. Naniesiono go po sygnałach strony radzieckiej, że Rada Najwyższa ZSRR jest nieprzychylna wycofaniu wojsk z Europy Środkowej, ze względu na brak przygotowanych mieszkań dla powracających żołnierzy ${ }^{13}$.

Największe rozbieżności, które pojawiły się w trakcie rozmów, dotyczyły kolejności i terminów ewakuacji wojsk radzieckich oraz wyznaczenia korytarzy transportowych. Strona radziecka zamierzała w pierwszej kolejności wycofać swoje siły z Niemiec, wykorzystując w tym celu zaplecze, jakie tworzyły radzieckie siły w Polsce. Dopiero potem nastąpiłaby ewakuacja z Polski. Rosjanie planowali realizować tranzyt przede wszystkim drogami kołowymi, przy czym przewidywali dwa korytarze transportowe: północny i południowy. Natomiast polska delegacja domagała się, by Rosjanie zakończyli ewakuację z Polski do końca 1991 r., wykorzystując transport lotniczy, kolejowy lub morski, ale nie kołowy. Rosjanie uznali ten termin za nierealny, poza tym podczas pierwszej tury rozmów przypomnieli o czekającym Polskę tranzycie ich sił z Niemiec. Polska przedstawiła projekt umowy o tranzycie 30 listopada 1990 r. $^{14}$

Druga tura rozmów odbyła się w Warszawie w dniach 11-12 grudnia $1990 \mathrm{r}$.

Strona radziecka podtrzymała stanowisko o kolejności ewakuacji: najpierw z Niemiec, a następnie z Polski, domagając się, by Polska respektowała postanowienia radziecko-niemieckiego porozumienia o ewakuacji. Dyskutowano także nad trasami tranzytowymi, kwestiami majątkowymi i stratami ekologicznymi. Wynikiem rozmów był jedynie protokół rozbieżności ${ }^{15}$.

Krzysztof Skubiszewski 18 grudnia 1990 r. wysłał do Edwarda Szewardnadze list z prośbą o potwierdzenie wycofania wojsk radzieckich z Polski do 31 grudnia 1991 r., ale nie uzyskał odpowiedzi ani od Szewardnadzego, ani od Aleksandra Biessmiertnycha, który 20 grudnia 1990 r. został nowym ministrem spraw zagranicznych ZSRR ${ }^{16}$.

W tej sytuacji MSZ podjąl decyzję, by z powodu braku umowy tranzytowej od 1 stycznia 1991 r. nie przepuszczać radzieckich jednostek udających się tranzytem z Niemiec do ZSRR (zakaz nie dotyczył rutynowego tranzytu do Królewca) ${ }^{17}$.

${ }^{13}$ Posiedzenie KSZ Senatu 25 I 1991, wystąpienie G. Kostrzewy-Zorbasa, s. 21-23.

${ }_{14}^{14}$ J. Strzelczy k, op. cit., s. 117-118, 137; szerzej o dylematach polskiej delegacji s. 134-138; K. Rogowicz, uważa, że termin do końca 1991 r. był nierealny, op. cit., s. 205; Posiedzenie KSZ Senatu 25 I 1991, wystąpienie G. Kostrzewy-Zorbasa, s. 21-23.

15 J. Strze l c zy k, op. cit., s. 139-140; Niemcy i ZSRR zawarly umowę o tranzycie, nie konsultując się w ogóle z Polską. ZSRR miał zapewnić współdziałanie Polski na własną rękę. Pominięcie Warszawy w rokowaniach dotyczących tranzytu strona polska wytykała następnie Niemcom, A. H a j n i c z, op. cit., s. 121.

${ }^{16}$ Posiedzenie KSZ Senatu 25 I 1991, wystąpienie J. Makarczyka, s. 16.

17 J. Strzelczyk, op. cit., s. 141-142. 
Kolejna tura rozmów w Moskwie 10 i 11 stycznia 1991 r. przebiegała zatem w napiętej atmosferze, na którą dodatkowo wpłynęły wydarzenia na Litwie ${ }^{18}$. Ustalono jedynie, że tranzyt powinien odbywać się na komercyjnych zasadach, ale nie określono wysokości stawek. Strona polska dopominała się także, by radzieccy żołnierze przejeżdżali przez Polskę nieuzbrojeni, a broń transportowano w zamkniętym wagonie. Atmosferę rozmów dodatkowo popsuło wystąpienie gen. Wiktora Dubynina, dowódcy Północnej Grupy Wojsk Armii Radzieckiej oraz pełnomocnika rządu ZSRR do spraw pobytu radzieckich wojsk w Polsce. Dubynin stwierdził, że Armia Radziecka, która przyniosła Polsce wolność, wyjdzie z Polski, kiedy uzna za stosowne, drogami, które uzna za stosowne, i w sposób, który sama ustali. W razie przeszkód - nie weźmie odpowiedzialności za bezpieczeństwo ludności Polski. Wystąpienie Dubynina nie było bynajmniej spontaniczne: zostało odczytane z karteczki. Polska delegacja była o krok od zerwania rozmów. Uratował je radziecki ambasador ad personam Walentin Koptielcew, stwierdzając, że wypowiedź Dubynina miała prywatny charakter. Jednak ku oburzeniu polskich negocjatorów Dubynin opublikował swoje wystąpienie w „Znamiach Pobiedy”, gazecie przeznaczonej dla stacjonujących w Polsce żołnierzy radzieckich. Trafiło ono także do redakcji polskich gazet, a stamtąd do opinii publicznej. W tej sytuacji, gdy 20 stycznia 1991 r. w Olszynie pojawił się radziecki konwój - Makarczyk zdecydował się go zatrzymać19.

\section{Informacja Ministerstwa Spraw Zagranicznych przedstawiona na posiedzeniu Komisji Spraw Zagranicznych Senatu 25 stycznia 1991 r.}

Na posiedzenie Komisji Spraw Zagranicznych Senatu przybył Jerzy Makarczyk i Grzegorz Kostrzewa-Zorbas. Jerzy Makarczyk poinformował, że podjął starania o usunięcie z Polski Wiktora Dubynina, ponieważ jego zachowanie i wypowiedzi dla prasy uznał za skandaliczne. Gdyby ZSRR nie chciał generała odwołać, był gotów uznać go za persona non grata i usunąć z Polski. Wypowiedzi Dubynina wskazywały, jego zdaniem, na trwający w ZSRR konflikt między rządem a kołami wojskowymi. Zapewnił ponadto, że nie zamierzał upokarzać ZSRR i armii radzieckiej, ale zapewnić jej bezpieczny przejazd przez Polskę ${ }^{20}$.

Makarczyk oświadczył, że jego celem było podpisanie odrębnych umów regulujących ewakuację i tranzyt radzieckich wojsk przez terytorium Polski. Wykluczał wykorzystanie zapisów wcześniejszych umów dwustronnych, ponieważ były to uzgodnienia narzucone, niekorzystne i zawierające terminologię nieodpowiednią w zmienionej sytuacji politycznej. W zamian chciał przekonać Rosjan, że Polska zapewni im tym korzystniejsze warunki ewakuacji, im krótszy będzie pobyt ich wojsk na jej terytorium ${ }^{21}$.

\footnotetext{
${ }^{18}$ M. Gorbaczow zażądał od litewskich władz 10 I 1991 r. natychmiastowego podporządkowania się organom ZSRR, pod groźbą konsekwencji. Po odmowie V. Landsbergisa doszło do zbrojnej interwencji radzieckich sił.

19 J. Strzelczy k, op. cit., s. 141-144.

${ }^{20}$ Posiedzenie KSZ Senatu 25 I 1991, wystąpienie J. Makarczyka, s. 18-19; o wewnętrznych podziałach w radzieckiej delegacji do rozmów z Polską w Moskwie pisze szerzej J. S tr ze lc zy k, op. cit., s. 143.

${ }^{21}$ Chodziło o umowę z 17 XII 1956 r. o statusie prawnym wojsk radzieckich czasowo stacjonujących w Polsce oraz kolejne porozumienia szczegółowe z 1957 r., K. R o g o w i c z, op. cit., s. 201; posiedzenie KSZ Senatu 25 I 1991, wystąpienie J. Makarczyka, s. 12-13, 21-22, 25.
} 
Zdaniem Makarczyka odrębny traktat o tranzycie był konieczny ze względu na rozmiar operacji. Z Niemiec należało wywieźć 380 tys. żołnierzy, a wraz z rodzinami około miliona osób, oprócz tego tysiące ton sprzętu, materiały nuklearne, chemiczne i inne. Podkreślając, że umowa radziecko-niemiecka o wycofaniu wojska nie wiązała Polski, zamierzał przekonać Rosjan, że Polska, jako państwo suwerenne, powinna podpisać odrębny traktat i kontrolować samodzielnie całą operację, a Związek Radziecki, który staje się państwem prawa, powinien także uznać, że prawo powinno dominować nad polityką, a nie odwrotnie. Jednocześnie zapewnił, że polskie stanowisko o konieczności podpisania traktatu w sprawie tranzytu zostało ze zrozumieniem przyjęte przez ministra spraw zagranicznych Niemiec ${ }^{22}$.

Makarczyk poinformował senatorów, że nie zgodzi się na tranzyt z Niemiec dopóty, dopóki nie zostaną wycofane radzieckie siły z Polski. Zamierzał też podtrzymać termin ewakuacji z Polski wojsk radzieckich do końca 1991 r., chociaż był gotów przesunąć tę datę do połowy 1992 r. W każdym razie jego celem było pozbycie się radzieckich wojsk przed szczytem transportów z Niemiec, przewidywanym na przełom 1992 i 1993 r. $^{23}$

Grzegorz Kostrzewa-Zorbas przedstawił szczegóły rozmów. Strona polska zamierzała do ewakuacji wykorzystać przede wszystkim kolej, a transport kołowy ograniczyć do minimum. Poza tym przekonywała Rosjan do rezygnacji z południowego korytarza transportowego, który biegł przez gęsto zaludnione tereny Polski i wiele gmin protestowało przeciw tranzytowi wojsk radzieckich przez ich terytorium ${ }^{24}$.

Grzegorz Kostrzewa-Zorbas poinformował, że strona radziecka wstępnie zgodziła się, by przejeżdżające tranzytem wojska podlegały polskiej jurysdykcji i były nieuzbrojone, wyjąwszy strażników i oficerów. Polska zaakceptowała ten wyjątek w trosce o zachowanie dyscypliny radzieckich żołnierzy. Eskorta transportów miała być jednak polska. W kwestii przewozu materiałów niebezpiecznych Polska chciała wykorzystać międzynarodowe umowy, co doradzało Ministerstwo Transportu, jednakże nie zamierzała zgodzić się na przewóz ładunków jądrowych, na co nalegała strona radziecka. Kwestie finansowe natomiast uzgodniono tylko w niewielkim stopniu. Grzegorz Kostrzewa-Zorbas zdementował komentarze radzieckiej i niemieckiej prasy, że Polska utrudnia rozmowy, by więcej zarobić na tranzycie. Niemniej wyraził przekonanie, że Polska w żadnym razie nie powinna ponosić kosztów tranzytu i opłaty przejazdowe powinny być ustalone na poziomie międzynarodowych taryf stosowanych na kolei i w transporcie drogowym. Rosjanie powinni

22 Traktat niemiecko-radziecki w sprawie wycofania wojsk radzieckich z Niemiec został parafowany 27 IX 1990 r., a podpisany 11 X 1990 r., Polska wobec zjednoczenia Niemiec 1989-1991. Dokumenty dyplomatyczne, red. Włodzimierz Borodziej, Warszawa 2006, s. 432; Posiedzenie KSZ Senatu 25 I 1991, wystąpienie J. Makarczyka, s. 12-14, 16-17.

${ }^{23} \mathrm{~W}$ innym miejscu J. Makarczyk mówił jednak o rozpoczęciu tranzytu, gdy tylko zostanie ustalony termin ewakuacji z Polski, Posiedzenie KSZ Senatu 25 I 1991, s. 14-15, 36-37. Makarczyk najwyraźniej chciał w ten sposób wymusić korzystną dla Polski datę ewakuacji armii radzieckiej z Polski. Taktykę tę miał „wymyślić” zdaniem A. Hajnicza G. Kostrzewa-Zorbas. A. Hajnicz uważał ją za nieskuteczną i błędną, op. cit., s. 121. Do tej taktyki odnosił się z rezerwą gen. Z. Ostrowski, członek polskiej delegacji, uważając, że była jedną z przyczyn impasu w rozmowach, K. Rogowicz, op. cit., s. 206. Rząd Polski dopuszczał przesunięcie terminu wycofania z 1991 r. na koniec pierwszego kwartału 1992 r., mówił o tym T. Mazowiecki w rozmowie z H. Kohlem 10 XI 1990 r., Zapis rozmowy T. Mazowieckiego z H. Kohlem z 10 XI 1990 r., Polska wobec zjednoczenia..., nr 84, s. 453.

${ }^{24}$ Posiedzenie KSZ Senatu 25 I 1991, wystąpienie J. Makarczyka, s. 19. 
też pokryć wszelkie szkody. Przy przekraczaniu granicy radzieckie transporty powinny podlegać cywilnej kontroli, łącznie z kontrolą osobową żołnierzy ${ }^{25}$.

Wiceminister obrony narodowej Janusz Onyszkiewicz zasadniczo akceptował stanowisko MSZ, jednak wskazał na konieczność jak najszybszego zawarcia traktatów i zakończenia ewakuacji radzieckich wojsk z Polski i Niemiec ze względu na pogarszającą się sytuację w Związku Radzieckim. Onyszkiewicz obawiał się, by w razie gwałtownego załamania radzieccy wojskowi nie podjęli niezależnych od Moskwy, samodzielnych działań. Wprawdzie radzieckie siły w Polsce były nieliczne i nie stanowiły problemu, to jednak niemiecki kontyngent był pokaźny i Polska na takie niebezpieczeństwo powinna być przygotowana ${ }^{26}$.

Andrzej Milczanowski z Urzędu Ochrony Państwa także nie kwestionował taktyki przyjętej przez MSZ i kolejności ewakuacji: najpierw z Polski, a następnie z Niemiec. Wskazał jednak, że podany przez MSZ termin do negocjacji, do końca 1991 r., był nierealny i można go było przedłużyć o 6 do 8 miesięcy. Milczanowski dopuszczał też pozostawienie w Polsce na czas ewakuacji z Niemiec specjalistycznych radzieckich jednostek, np. łączności, których liczebność (zapewne 2-3 tys.) określiliby polscy eksperci. Milczanowski wspomniał, że w ZSRR coraz częściej rozważa się ewakuację drogą morską i lotniczą, a także przez Czechosłowację. Generalnie w kwestii wyznaczenia daty ewakuacji z Polski i pozostawienia na czas tranzytu wybranych radzieckich jednostek doradzał MSZ elastycznośćc ${ }^{27}$.

Makarczyk zapewnił, że jego stanowisko było elastyczne, ale Rosjanie nie zareagowali na sygnały, że Polska byłaby gotowa negocjować datę ewakuacji i po prostu nie podali żadnego (poza 1994 r.) nowego terminu. Gdyby zgodzili się na rok 1992, można było natychmiast podpisać porozumienie i rozpocząc tranzyt. Makarczyk uznał plotki o alternatywnej trasie przez Czechosłowację za formę nacisku wywieraną na Polskę i groźbę, że nie tylko nie zarobi na tranzycie, ale opóźni wycofanie radzieckich sił. Osobiście uważał, że wybór trasy omijającej Polskę byłby korzystny. Sądził, że Polska nie tylko nie zarobi na tranzycie, ale będzie miała problem z wyrównaniem strat. Co innego, gdyby zamiast niepewnego płatnika, jakim był ZSRR, koszty transportu pokrywały Niemcy. Poinformował, że MSZ prowadził z Niemcami rozmowy w tym kierunku, ale nie był pewny, jaka byłaby na nie reakcja Rosjan ${ }^{28}$.

Makarczyk zdecydowanie odrzucał możliwość pozostawienia w Polsce radzieckich sił na czas tranzytu z Niemiec. Podejrzewał Rosjan, że będą zawyżali liczbę potrzebnych żołnierzy (np. do 25 tysięcy), by samodzielnie kierować ruchem swych jednostek. Tymczasem bezpieczeństwo tranzytu ma zapewnić strona polska. Godził się zatrzymać

${ }_{25}$ Posiedzenie KSZ Senatu 25 I 1991, wystąpienie G. Kostrzewy-Zorbasa, s. 25-29.

26 Posiedzenie KSZ Senatu 25 I 1991, s. 32-33.

27 Posiedzenie KSZ Senatu 25 I 1991, s. 34-35, 72.

${ }^{28}$ Posiedzenie KSZ Senatu 25 I 1991, s. 36-37. W trakcie rozmów z H. Kohlem T. Mazowiecki wyraził przekonanie, że ZSRR nie pokryje kosztów strat, jakie Polska poniesie w wyniku tranzytu, z tego powodu Niemcy powinny mieć w tych kosztach swój udział, tym bardziej, że zawierając układ o ewakuacji z ZSRR, nie konsultowały się z Polską. H. Kohl zgodził się na rozmowy ekspertów, ale jako element szerszych rozmów gospodarczych i uchylił się od zobowiązań finansowych. Podkreślił natomiast, że w interesie Polski i Niemiec leżała szybka ewakuacja wojsk radzieckich. Zapis rozmowy T. Mazowieckiego z H. Kohlem z 10 XI 1990 r., Polska wobec zjednoczenia..., nr 84, s. 453-454. 
w Polsce na czas tranzytu radzieckich oficerów łączności, ale na etatach dyplomatycznych, a nie wojskowych, deklarując, że może wystawić nawet sto takich etatów ${ }^{29}$.

Przebieg rozmów z Rosjanami otwarcie krytykowali eksperci Ośrodka Studiów Międzynarodowych Senatu, w tym jego dyrektor Artur Hajnicz i Marek Jerzy Nowakowski. Artur Hajnicz przyznał, że choć decyzja o opóźnieniu negocjacji w sprawie wycofania radzieckich wojsk z Polski przed zakończeniem rozmów $2+4$, była słuszna, to przyjęta przez MSZ linia negocjacji zawiodła i Polska pozostała bez układu o tranzycie, i bez układu o wycofaniu wojsk radzieckich ${ }^{30}$.

Artur Hajnicz, po rozmowie z przewodniczącym delegacji Rady Najwyższej ZSRR bawiącej w sejmie 7 stycznia 1991 r., uznał, że ZSRR świadomie zwlekał z ustaleniem daty ewakuacji z Polski, aby przerzucić na Polskę odpowiedzialność za opóźnienie ewakuacji z Niemiec. Gdyby opinia o polskiej obstrukcji utrwaliła się w krajach europejskich, doprowadziłoby to do izolacji Polski. Hajnicz poinformował o pojawiających się w niemieckiej prasie nieprzychylnych komentarzach, sugerując, by MSZ rozważyło zmianę taktyki, aby odpowiedzialność za opóźnienia spadła na ZSRR. Zaproponował także, by Komisja Spraw Zagranicznych Senatu wysłała do Bundestagu delegację z zadaniem wyjaśnienia polskiego stanowiska ${ }^{31}$.

Marek Jerzy Nowakowski uważał, że ewakuacja radzieckich wojsk nie dotyczyła wyłącznie Polski, ZSRR i Niemiec, ale miała wymiar europejski, którego Makarczyk nie doceniał, podobnie jak dynamiki rozwoju sytuacji w ZSSR, gdzie do głosu dochodzili jak sądził za zgodą Gorbaczowa - przeciwnicy wycofania wojsk z Europy Środkowej. Jego zdaniem radzieckie wojska mogłyby stanowić zagrożenie, w razie gdyby Polska znalazła się w izolacji, a nieprzejednane stanowisko w negocjacjach z ZSRR nie znajdowało zrozumienia w Niemczech i USA. Nowakowski stwierdził, że nawet jeśli gen. Dubynin nie podał terminu wycofania radzieckich wojsk z Polski z czystej złośliwości, to pozostaje faktem, że terminu nie uzgodniono. Wskutek tego z polskiej strony konieczna była większa elastyczność, w czym utwierdziły go rozmowy z doradcami Borysa Jelcyna, którzy także nie popierali sztywnego stanowiska Polski w kwestii ewakuacjii ${ }^{32}$.

Obaj eksperci OSM Senatu sugerowali, by rozmowy toczyć w trójkącie z Niemcami, co uniemożliwiłoby ZSRR rozgrywanie kwestii tranzytu przeciw Polsce. Niemcy mogłyby też wywierać nacisk na ZSRR w tej sprawie. Ponadto zalecali, żeby większy nacisk położyć na datę rozpoczęcia ewakuacji, a nie jej zakończenia. Nowakowski proponował wprowadzić dwu-trzymiesięczne moratorium na tranzyt, które można by przerwać, gdyby rozmowy nie postępowały. Wobec powszechnej w ZSRR niechęci do wycofania wojsk radzieckich, także $\mathrm{w}$ środowiskach demokratycznych, Polska mogłaby porozumieć się z Niemcami odnośnie do współudziału polskich wykonawców w budowie domów dla żołnierzy wycofywanych do ZSRR ${ }^{33}$.

${ }^{29}$ Posiedzenie KSZ Senatu 25 I 1991, s. 36-37.

30 Posiedzenie KSZ Senatu 25 I 1991, s. 39.

31 Posiedzenie KSZ Senatu 25 I 1991, s. 40-43. A. Hajnicz w opinii z 31 XII 1990 r., sporządzonej dla K. Skubiszewskiego, doradzał, by podkreślać dążenie do szybkiego wyjazdu wojsk radzieckich z Polski i Niemiec, a kwestie materialne odłożyć na później, by nie stwarzać fatalnego wrażenia, że Polska chce na tranzycie zarobić, Polska wobec zjednoczenia ..., nr 86, s. 86; A. H a j n i c z, op. cit., s. 121.

32 Posiedzenie Komisji Spraw Zagranicznych Senatu 25 I 1991, s. 45-47.

33 Posiedzenie Komisji Spraw Zagranicznych Senatu 25 I 1991, s. 47-48. 


\section{Opinie i wątpliwości senatorów}

Wśród senatorów przeważał pesymizm, jeśli chodzi o wynik rozmów z Rosjanami. Edward Wende po rozmowie z delegacją Rady Najwyższej ZSRR odniósł wrażenie, że Rosjanie źle znoszą naciski w sprawie ewakuacji i podtrzymają nieprzejednane stanowisko. Wysłanie do Niemiec delegacji Komisji Spraw Zagranicznych Senatu w celu przedstawienia polskiego stanowiska uznał za interesujące ${ }^{34}$.

Wyjazd do Niemiec delegacji Senatu poparła także Dorota Symonides, poruszona antypolskimi nastrojami wśród ludności w RFN. Zgadzała się jednak z Makarczykiem, by Rosjanie w pierwszej kolejności wycofali się z Polski, ponieważ pozwoliłoby to zorientować się, co Polskę czeka przy tranzycie. Zwróciła uwagę na konieczność akcji propagandowej w polskim społeczeństwie, aby uniknąć prowokacji. Uważała, że Niemcy mogłyby ponieść część kosztów tranzytu, skoro zdecydowali się zapłacić Rosjanom za wycofanie wojska ${ }^{35}$.

Jerzy Dietl także poparł akcję informacyjną na poziomie parlamentów, zwłaszcza w Niemczech. Pytając Jerzego Makarczyka, czy prowadzone są z Niemcami rozmowy w sprawie tranzytu na szczeblu wyższym niż ambasadorów, poprosił o opinię, czy kryzys w republikach bałtyckich mógł wpłynąć na usztywnienie radzieckiego stanowiska. Indagował też o możliwość „uruchomienia nacisków ze strony USA”? Podobnie jak Wende demonstrował pesymizm w kwestii ewakuacji wojsk radzieckich z Polski, uważając, że istnieje małe pole manewru w tej sprawie ${ }^{36}$.

Jerzy Makarczyk bronił stanowiska MSZ, kierowanego, jak to określił, przez „profesorów prawa", by nie rozpoczynać ewakuacji i tranzytu bez podpisanych porozumień. Argumentował, że małe i słabe państwo musi szukać wsparcia w prawie międzynarodowym. Przypomniał, że ZSRR podpisał przecież umowy o ewakuacji z innymi państwami - w końcu listopada 1990 r. podpisał układ o redukcji wojsk konwencjonalnych, określający maksymalną liczbę wojsk na terenie poszczególnych państw. Polska na mocy tego traktatu mogła te wojska kontrolować. Wprawdzie w praktyce nie mogła tego robić, ale traktat musiał istnieć, by móc stwierdzić jego złamanie ${ }^{37}$. Argumentował, że rezygnacja $\mathrm{z}$ opieki prawa rodzi obawę powrotu do stanu istniejącego w PRL. Partnerzy niemieccy, jego zdaniem, doskonale to rozumieli. Odrzucił argumentację Artura Hajnicza, zarzucając mu kierowanie się doniesieniami prasy, która może być inspirowana przez różne siły. W dodatku poinformował, że deputowany Szarin w rozmowie z przedstawicielami MSZ wykazywał większe zrozumienie odnośnie do rozwiązania sprawy radzieckich wojsk niż w rozmowach z parlamentarzystami. Jego taktyka, by w ten sposób wywrzeć nacisk na MSZ, była dla Makarczyka oczywista. Polskie MSZ było elastyczne i dopuszczało termin zakończenia ewakuacji w 1992 r. Makarczyk poparł natomiast postulat Artura Hajnicza, by delegacja parlamentarna popularyzowała i thumaczyła polskie stanowisko za granicą ${ }^{38}$.

${ }^{34}$ Posiedzenie Komisji Spraw Zagranicznych Senatu 25 I 1991, s. 50-51.

35 Posiedzenie Komisji Spraw Zagranicznych Senatu 25 I 1991, s. 54-55.

${ }^{36}$ Posiedzenie Komisji Spraw Zagranicznych Senatu 25 I 1991, s. 57.

37 Traktat o redukcji zbrojeń konwencjonalnych w Europie został podpisany 19 XI 1990 r. Ustalono w nim limity poszczególnych rodzajów uzbrojenia NATO i Układu Warszawskiego na obszarze od Atlantyku po Ural. Przewidywał likwidację 250 tys. jednostek bojowych, przede wszystkim w Europie Środkowej do roku 1994, J. K u k ułk a, Historia wspótczesna stosunków międzynarodowych 1945-1994, Warszawa 1995, s. 431.

38 Posiedzenie KSZ Senatu 25 I 1991, s. 60-63. 
Makarczyk zapewnił, że ze swej strony przedstawi polskie stanowisko w rozmowie z sekretarzem generalnym NATO Manfredem Wörnerem, sekretarzem generalnym Unii Zachodnioeuropejskiej Wim van Eekelenem, który miał przybyć do Polski około połowy lutego, oraz podczas spotkania Rady Ministrów Rady Europy, planowanego na 22-23 lutego. Uspokajał, że Rosjanom nie udało się wbić klina między Polskę a Europę, czego dowodem była rychła perspektywa przyjęcia Polski po wyborach prezydenckich do Rady Europy ${ }^{39}$.

Zdaniem Makarczyka radzieckie argumenty o braku mieszkań dla ewakuowanych żołnierzy były nieuczciwe. W Polsce stacjonowało 40 tys. radzieckich żołnierzy, natomiast w Niemczech 380 tys. Na pytanie Hajnicza, czy nie można by jednak rozpocząć tranzytu przed zawarciem traktatu, Makarczyk przyznał, że można by tak zrobić, ale co by się stało, gdyby Rosjanie wycofali się wówczas z negocjacji i podpisania traktatu? Taki scenariusz uważał za bardzo prawdopodobny, zważywszy zanik w ZSRR ,europejsko-cywilizowanego zachowania”. Zwolenników „elastyczności” pytał, co będzie, jeśli zawiodą środki dyplomatyczne? Janusz Onyszkiewicz uspokajał, że Polska posiada narzędzie nacisku, zaopatrując radzieckie wojska we wszystkie media ${ }^{40}$.

Grzegorz Kostrzewa-Zorbas argumentował, że Polska proponowała ZSRR bardziej elastyczne terminy zakończenia ewakuacji niż inne kraje regionu, w dodatku nie kwestionowała ważności podpisanych w przeszłości umów, jak zrobiła to Czechosłowacja, przyjmując stanowisko, że umowy o stacjonowaniu wojsk radzieckich z 1968 r. były narzucone, a tym samym nieważne. Kostrzewa-Zorbas podzielał pogląd, że Polska nie powinna stać się ostatnim krajem, z którego wycofają się radzieckie wojska, co świadczyłoby, że dla ZSRR Polska stanowi nadal teren radzieckiej strefy bezpieczeństwa o obniżonej suwerenności. Jego zdaniem obecność nawet 500 radzieckich żołnierzy stawiałaby Polskę w roli państwa zwasalizowanego, co zamknęłoby jej drogę do Europy. Poinformował, że Polska złożyła ofertę w sprawie udziału polskich przedsiębiorstw w budowaniu osiedli dla radzieckich żołnierzy. Rozwiał natomiast nadzieje, że Niemcy zapłacą za tranzyt przez Polskę $e^{41}$.

W sprawie możliwości negocjacji w trójkącie z Niemcami Kostrzewa-Zorbas stwierdził, że nie powinny one dotyczyć kwestii politycznych, ale technicznych, a na te nie przyszła jeszcze pora, jako że będzie je można podjąć dopiero po ustaleniu daty wycofania wojska. Kostrzewa-Zorbas oznajmił na koniec, że otrzymał sygnały, jakoby wkrótce Rosjanie mieli określić termin wycofania wojsk z Polski, ale była to informacja poufna ${ }^{42}$.

Andrzej Stelmachowski, mimo argumentów MSZ, zaapelował jednak o większą elastyczność w rozmowach z Rosjanami, wystrzeganie się postawy nieprzejednanej i uwzględnienie prestiżu ZSRR, zwłaszcza w obliczu niepowodzeń, których Rosjanie do-

39 Posiedzenie KSZ Senatu 25 I 1991, s. 63-64.

${ }^{40}$ Posiedzenie KSZ Senatu 25 I 1991, s. 66, 76.

${ }^{41}$ Posiedzenie KSZ Senatu 25 I 1991, s. 68-70 i 94; o tym, że Niemcy nie chcą płacić za tranzyt przez terytorium Polski, poinformował także ambasador RFN w Polsce Günter Knackstedt w rozmowie z K. Skubiszewskim 4 II 1991 r. Notatka informacyjna ministra spraw zagranicznych z rozmowy z ambasadorem RFN 4 II 1991 r., Polska wobec zjednoczenia..., nr 87, s. 471.

${ }^{42}$ Posiedzenie KSZ Senatu 25 I 1991 r., s. 71. K. Skubiszewski nie życzył sobie dobrych usług Niemiec w rozmowach z ZSRR, o czym poinformował ambasadora RFN G. Knackstedta 4 II 1991 r., twierdząc, że nie upoważnił ambasadora w Bonn J. Reitera do prośby o pomoc w tej sprawie, Polska wobec zjednoczenia..., nr 87, s. 472; K. Skubiszewski nie życzył sobie umiędzynarodowienia tej sprawy, o czym poinformował posłów 27 II 1991 r., K. Rog ow ic z, op. cit., s. 212. 
świadczali na odcinku państw bałtyckich i w polityce wewnętrznej. Sugerując, by gestami dobrej woli przezwyciężyć zaistniały impas, rozważał wybudowanie około 4 tys. mieszkań dla ewakuowanych żołnierzy radzieckich, proponował też przedłużenie podciągniętej do Katowic szerokotorowej kolei, tzw. siarkowej, dzięki czemu powstałaby bezpośrednia linia tranzytowa z Niemiec do ZSRR. Dla tej inwestycji można było szukać finansowego wsparcia w RFN. Przekonywał, że oprócz kija powinna być w tych rozmowach także marchewka, tym bardziej że z kijem w przypadku Polski było bardzo krucho ${ }^{43}$.

Janusz Onyszkiewicz wskazał na konieczność polepszenia wizerunku Polski w oczach radzieckich żołnierzy. Mimo że w Polsce był raczej niewykonalny gest Niemców, którzy stacjonującym u nich żołnierzom przysłali paczki na święta, to przyjazne gesty powinny się pojawić: na przykład rodziny ewakuowanych żołnierzy radzieckich mogłyby pozostać w Polsce dłużej, choćby do 1994 r., aż ZSRR zapewni im u siebie warunki bytowe ${ }^{44}$.

Twarde stanowisko MSZ w rozmowach z Rosjanami poparł natomiast Stanisław Obertaniec, senator z Legnicy (,elastyczność jest dobra w przypadku szelek, ale w polityce może się łatwo przekształcić w serwilizm i wtedy partnera przestaje się szanować"). Dostrzegał on konieczność gestów dobrej woli w stosunku do żołnierzy stacjonujących w Polsce, znał też ich obawy, że po powrocie do ZSRR wylądują pod namiotami. W Polsce było dużo rodzin, które posyłały dzieci do szkół i żyły na dobrym poziomie. Podobnie jak Onyszkiewicz uważał, że mogłyby zostać dłużej, natomiast wojska liniowe, ofensywne, broń, należało ewakuować do końca 1992 r., tak jak planował rząd. Za niepokojące Obertaniec uznał formułowanie przez niektórych prezydentów miast goszczących Rosjan gróźb, że odetną Rosjanom media. Jego zdaniem były to działania nieodpowiedzialne i wykraczające poza ich kompetencje. Takie przypadki „wymachiwanie szabelką” rozdmuchiwała radziecka prasa. Zdaniem Obertańca należało położyć temu kres, tym bardziej że nie było powodu, by upokarzać radzieckich żołnierzy. Obertaniec wskazał natomiast na konieczność większej aktywności Urzędu Ochrony Państwa w Legnicy, gdzie wyroili się oficerowie KGB i składali liczne wizyty polskim wojskowym ${ }^{45}$.

Następnie Stanisław Dembiński otworzył dyskusję nad ewentualnym przyjęciem uchwały, której projekt przygotował OSM. Stwierdzono w nim, że w rozmowach z ZSRR dotyczących wycofania Północnej Grupy Wojsk Radzieckich z Polski i tranzytu wojsk radzieckich z Niemiec pojawił się problem z ustaleniem jakiegokolwiek terminu ewakuacji. Wiąże się to z rozwojem sytuacji w ZSRR, który chce przerzucić odpowiedzialność za utrudnianie wycofania wojska $\mathrm{z}$ Niemiec na stronę polską, co może negatywnie wpłynąć na rokowania polsko-niemieckie w sprawie traktatu ogólnego, może też utrudnić ratyfikację traktatu granicznego. W związku z tym Komisja Spraw Zagranicznych Senatu postanawia wysłać delegację do Komisji Spraw Zagranicznych Bundestagu, żeby wyjaśnić polskie stanowisko oraz zaprosić delegację Komitetu Spraw Zagranicznych Rady Najwyższej Republiki Rosyjskiej (w ramach rewizyty po ubiegłorocznej wizycie Andrzeja Stelmachowskiego i Janusza Ziółkowskiego) w celu omówienia nowej sytuacji, a także sposobów wycofania wojsk radzieckich z Polski i zagadnienia tranzytu ${ }^{46}$.

\footnotetext{
43 Posiedzenie KSZ Senatu 25 I 1991, s. 73-75.

${ }^{44}$ Posiedzenie KSZ Senatu 25 I 1991, s. 76-77.

45 Posiedzenie KSZ Senatu 25 I 1991, s. 78-82.

${ }^{46}$ Posiedzenie KSZ Senatu 25 I 1991, s. 83, 120.
} 
Większość senatorów z rezerwą odniosła się do propozycji przyjęcia uchwały. Zastanawiano się, czy nie wystarczyłaby informacja dla prasy. Poza tym wątpliwości budziła kwestia, czy w ogóle angażować Niemcy w rozmowy z Rosjanami i w jakim stopniu to robić. Stanisław Stomma był zdecydowanie przeciwny, by uchwała, co do której nie był ostatecznie przekonany, zawierała odniesienia do Niemiec. Obawiał się, że Rosjanie mogliby potraktować porozumienie polsko-niemieckie za z gruntu antyradzieckie. Z tego też powodu, by nie urażać Rosjan, był nieprzychylny wysyłaniu delegacji do Niemiec. Jego zdaniem stosunki polsko-niemieckie i polsko-radzieckie powinny być traktowane osobno ${ }^{47}$.

Edward Wende poparł stanowisko Stommy, gdyby uchwała miała zostać opublikowana. Natomiast, gdyby pozostała wewnętrznym dokumentem Komisji, to mogła pozostać $\mathrm{w}$ proponowanej formie ${ }^{48}$.

Tadeusz Kłopotowski wskazał, że należałoby skończyć z praktyką odwiedzin wyłącznie w krajach przychylnych Polsce. Powinno się wybierać także kraje trudne, ale dla Polski ważne, $\mathrm{z}$ tego powodu dobrze byłoby przemyśleć wizytę nie tylko w Radzie Najwyższej Rosji, ale i w Radzie Najwyższej ZSRR ${ }^{49}$.

Andrzej Stelmachowski by przeciwny przyjmowaniu uchwały. Uważał, że w Niemczech polskie stanowisko mogłaby przedstawić niejako „przy okazji” delegacja udająca się do Bundestagu w sprawie odszkodowań. Co do propozycji Kłopotowskiego, by złożyć wizytę w ZSRR, wskazywał na skomplikowaną sytuację w tym kraju, zwracając uwagę, że jeśli polska delegacja złożyłaby wizytę w Radzie Najwyższej Rosji, byłby to gest w stronę Borysa Jelcyna, a ewakuacja jest kwestią radziecką ${ }^{50}$.

Włodzimierz Bojarski przypomniał o potrzebie utrzymywania kontaktów z republikami bałtyckimi, Białorusią i Ukrainą. Stanisław Obertaniec uważał jednak, że nawet jeśli ZSRR przetrwa tylko jeszcze rok, to należy sprawę ewakuacji załatwić z ZSRR ${ }^{51}$.

Do zgłoszonych uwag i propozycji ponownie odniósł się Kostrzewa-Zorbas, który wyjaśnił, że po analizach wykluczono przedłużenie kolei „siarkowej”, uznając to przedsięwzięcie za nieopłacalne. Niemniej istniała możliwość (wobec spadku krajowych przewozów towarowych nawet o 40 \%) wyznaczenia czterech linii kolejowych o dużej mocy przewozowej na różnych szerokościach geograficznych. Przekazano tę informację Rosjanom, by łatwiej przyjęli rezygnację z południowej trasy kołowej ${ }^{52}$.

Kostrzewa-Zorbas przyznał, że zachodnioeuropejskie republiki radzieckie obawiały się, by ewakuowane siły nie trafiły na ich terytorium. Ten lęk wynikał, jego zdaniem, z nieznajomości wynegocjowanego w Wiedniu i podpisanego w Paryżu traktatu o redukcji wojsk konwencjonalnych, który zabraniał ich przenoszenia w inne miejsce. Kostrzewa-Zorbas postulował, żeby tłumaczyć to Frontom Ludowym działającym w republikach radzieckich, ponieważ ich wiedza na ten temat była bardzo niewielka ${ }^{53}$.

${ }^{47}$ Posiedzenie KSZ Senatu 25 I 1991, s. 83-84, wydaje się, że Rosjanie nie mieli takich skrupułów i starali się wywrzeć za pośrednictwem Niemiec presję na polskiego negocjatora. Notatka informacyjna ministra spraw zagranicznych z rozmowy z ambasadorem RFN 4 II 1991 r. Polska wobec zjednoczenia..., nr 87, s. 471.

48 Posiedzenie KSZ Senatu 25 I 1991, s. 85.

49 Posiedzenie KSZ Senatu 25 I 1991, s. 87-88.

50 Posiedzenie KSZ Senatu 25 I 1991, s. 88-89.

${ }^{51}$ Posiedzenie KSZ Senatu 25 I 1991, s. 90, propozycja W. Bojarskiego wynikała zapewne z obaw, jakie miały republiki radzieckie, zwłaszcza Ukraina, że wycofywane wojska trafią na ich terytorium.

52 Posiedzenie KSZ Senatu 25 I 1991, s. 91-92.

53 Posiedzenie KSZ Senatu 25 I 1991, s. 92-93. 
Marek Jerzy Nowakowski bronił projektu złożenia wizyty w parlamencie Rosji. Wprawdzie głównym partnerem był parlament radziecki, ale w rosyjskim skupiały się demokratyczne siły Rosji. Demokraci także byli przeciwni szybkiemu wycofaniu radzieckich wojsk, ale im można było przynajmniej wytłumaczyć polskie stanowisko. Nowakowski uważał, że wycofanie radzieckich wojsk z Polski jest testem jej suwerenności, niemniej w przeciwieństwie do optymizmu demonstrowanego przez przedstawicieli MSZ, pesymistycznie przewidywał, że wspomniany test Polska przegra i lepiej byłoby proces wycofania wojsk popychać drogą ustępstw i elastyczności, niż zupełnie ponieść porażkę $e^{54}$.

Po przerwie Komisja Spraw Zagranicznych Senatu zebrała się już tylko we własnym gronie. Przewodniczący podsumował dyskusję, stwierdzając, że Komisja zalecała większą elastyczność w rozmowach z Rosjanami i nie tylko stawianie na literę prawa, jak robił to MSZ. Zaznaczył jednak, że to nie Komisja, a MSZ prowadzi politykę zagraniczną. Przypomniał, że nie zdecydowano, czy w protokole jako zalecenie ma się znaleźć kontakt z parlamentami Niemiec, ZSRR i ewentualnie Rosji oraz czy ma to być wspólna akcja z Komisją Spraw Zagranicznych Sejmu. Uznał, że na taką akcję skierowaną na opinię publiczną w tych krajach jest przyzwolenie i jest to zgodne z zadaniami parlamentu ${ }^{55}$.

W dyskusji, które parlamenty objąć akcją informacyjną, Jerzy Kłoczowski wymienił Francję, Włochy, ewentualnie Wielką Brytanię. Opowiedział się przy tym za akcją wyłącznie Senatu, ponieważ delegacja sejmu ciągle była przyjmowana z pewną dozą nieufności. Wyraził też wątpliwość, czy polskie ambasady dostatecznie informują zagraniczną opinię publiczną o polskim stanowisku. August Chełkowski dodał parlament Rosji, Edward Wende opowiedział się za równoległymi rozmowami z Rosją i ZSRR, Józef Dietl tylko za wizytą w ZSRR. Zaapelował przy tym, by ewentualny wyjazd senackiej delegacji do państw zachodnich był dobrze przygotowany (,zz referatem, a nie jakaś wycieczka") $)^{56}$.

Pewien niepokój senatorów wywołała różnica zdań między delegacją MSZ a ekspertami OSM Senatu. August Chełkowski niepokoił się, czy OSM ma dobrych informatorów. Jednak Józef Dietl i Tadeusz Kłopotowski uznali zaprezentowaną różnicę zdań za mieszczącą się w granicach normy ${ }^{57}$.

Ostatecznie Komisja Spraw Zagranicznych Senatu zrezygnowała z uchwały i poprzestała na zapisie w protokole, w którym stwierdzono, że Komisja wysłuchała komunikatu MSZ, MON i Urzędu Ochrony Państwa o stanie rozmów w sprawie tranzytu radzieckich wojsk z Niemiec przez Polskę i wycofania wojsk radzieckich z Polski. Wyraziła zaniepokojenie przedłużającymi się negocjacjami i brakiem terminu wycofania wojsk radzieckich z Polski. Uznała za ważne poinformowanie światowej opinii, że Polska nie utrudnia wycofania radzieckich wojsk z Niemiec, tylko dąży do prawno-organizacyjnego uregulowania tej kwestii ${ }^{58}$.

\footnotetext{
54 Posiedzenie KSZ Senatu 25 I 1991, s. 94-95.

55 Posiedzenie KSZ Senatu 25 I 1991, s. 96-97.

56 Posiedzenie KSZ Senatu 25 I 1991, s. 98-105.

57 Posiedzenie KSZ Senatu 25 I 1991, s. 99-100, 104-106.

58 Posiedzenie KSZ Senatu 25 I 1991, s. 108-109, 119.
} 


\section{Zmiana stanowiska negocjacyjnego Ministerstwa Spraw Zagranicznych}

Przebieg dyskusji w Senacie ujawnił poważne wątpliwości co do słuszności taktyki przyjętej przez MSZ w rozmowach z ZSRR. Większość Senatorów, ale i członkowie rządu doradzali większą „elastyczność” w rozmowie z Rosjanami. Wprawdzie Komisja Spraw Zagranicznych Sejmu na posiedzeniu 27 lutego 1991 r., obradująca z udziałem Krzysztofa Skubiszewskiego, zaakceptowała politykę rządu, jednak przebieg dyskusji w Senacie świadczył o braku szerszego poparcia dla twardej linii proponowanej przez Jerzego Makarczyka ${ }^{59}$.

W dniach od 25 do 27 lutego 1991 r. w Niemczech przebywała delegacja Senatu, w której składzie znaleźli się: Stanisław Dembiński, Franciszek Sobieski, Andrzej Szczypiorski, Dorota Symonides, Artur Hajnicz. Między 25 a 27 lutego 1991 r. spotkała się z ministrem spraw zagranicznych Niemiec Hansem Dietrichem Genscherem, przewodniczącą Bundestagu Ritą Süssmuth, przedstawicielem CDU Karlem Hansem Hornhuesem, przedstawicielem SPD Karstenem Voigtem, przewodniczącym Komisji Spraw Zagranicznych Bundestagu Hansem Streckenem, i Komisji Spraw Zagranicznych Bundesratu Gerhardem Schröderem. Polska delegacja - zgodnie z duchem ustaleń z 25 stycznia 1991 r. przekonywała, że Polska nie chce utrudniać ewakuacji z Niemiec, ale oczekuje współpracy w tej sprawie. Tranzyt przez Polskę nie może być traktowany przez zainteresowane państwa jako tranzyt przez ziemię niczyją ${ }^{60}$.

Delegację Senatu wracającą z Niemiec przyjął premier Jan Krzysztof Bielecki, który przygotowywał się do wizyty w Niemczech. Artur Hajnicz uważa, że pod wpływem tego spotkania premier w rozmowie z Helmutem Kohlem, ,jednoznacznie stwierdził, że nie istnieje iunctim pomiędzy tranzytem a wycofaniem sowieckich wojsk z Polski ${ }^{61}$ '. Z tą opinią można dyskutować. W trakcie rozmowy z Helmutem Kohlem 5 marca 1991 r. Bielecki przekonywał, że kwestia tranzytu wykracza poza dwustronne stosunki. Ostrzegając przed oskarżeniami Polski o opóźnienie tranzytu, oświadczył, że jego realizacja nie wymaga pozostawienia radzieckich sił w Polsce. Jako dowód podał radziecką propozycję skierowania tranzytu przez Czechosłowację, którą radzieckie wojska miały opuścić przed końcem 1991 r. Zapewnił, że Polska jest elastyczna w kwestii wycofania wojsk radzieckich, ale ZSRR także powinien okazać w tej sprawie elastycznośćc ${ }^{2}$. Jednak nie zadeklarował, że Polska wycofa się ze stawiania warunku ewakuacji radzieckich sił przed rozpoczęciem tranzytu, chociaż w następnych miesiącach tak się właśnie stało.

W związku z tranzytem radzieckich wojsk z Niemiec MSZ znalazło się pod silną presją. 26 stycznia 1991 r. rzecznik prasowy radzieckiego MSZ Witalij Czurkin stwierdził, że zatrzymując konwój z pomocą humanitarną, Polska naruszyła prawa człowieka. Ambasador RFN w Warszawie ostrzegł 4 lutego 1991 r. Krzysztofa Skubiszewskiego, że niemiecka opinia publiczna może obciążyć Polskę odpowiedzialnością za opóźnienie ewakuacji wojsk radzieckich z Niemiec. Doradzał również ,ze względu na prestiż armii ra-

${ }^{59}$ K. R o gowicz, op. cit., s. 212-213.

${ }^{60}$ A. Hajnicz, op. cit., s. $122-123$.

${ }^{61}$ A. Hajnicz, op. cit., s. 123.

${ }^{62}$ Zapis rozmowy J. K. Bieleckiego z kanclerzem H. Kohlem 5 III 1991 r., Polska wobec zjednoczenia..., nr 89, s. 476-477. 
dzieckiej” większą elastyczność, zwłaszcza w niektórych „mniej istotnych punktach”, do których zaliczył dopuszczenie Rosjan do kontroli bezpieczeństwa tranzytu przez Polskę ${ }^{63}$.

W efekcie MSZ zdecydowało się na większą ,elastyczność”. W dniu 8 lutego $1991 \mathrm{r}$. Polska wpuściła konwój zatrzymany 20 stycznia. Kolejne konwoje humanitarne, czy też zdaniem polskiej strony „humanitarne”, postanowiono umieszczać na platformach kolejowych i przewozić do granicy z ZSRR. Po otrzymaniu tej oferty Rosjanie, którym najwyraźniej zależało na „wybiciu” sobie drogi kołowej przez południową Polskę - przestali podstawiać kolejne humanitarne konwoje ${ }^{64}$.

Podczas czwartej tury rozmów w Warszawie (11-13 lutego 1991 r.) Rosjanie zaproponowali rozpoczęcie ewakuacji z Polski w maju 1991 r., a zakończenie w połowie 1994 r. Argumentowali, że chcą zabezpieczyć tranzyt z Niemiec. 12 lutego 1991 r. prezydent Lech Wałęsa spotkał się z radzieckim chargé d'affaires Lwem Klepackim, po czym zwołał 13 lutego posiedzenie Rady Bezpieczeństwa Narodowego, na którym twarda linia MSZ także nie zyskała poparcia ${ }^{65}$.

W tej sytuacji 18 marca 1991 r. Krzysztof Skubiszewski wyraził gotowość rozpoczęcia tranzytu przez terytorium Polski w oparciu o negocjowany traktat, a podczas szóstej rundy rozmów (11-12 kwietnia 1991 r.) Polska wyraziła zgodę na rozpoczęcie tranzytu „W ograniczonym zakresie” przed podpisaniem umowy. W maju 1991 r. ruszył tranzyt radzieckich wojsk z Niemiec przez Polskę koleją; odbywał się na koszt Polski, ponieważ od stycznia1991 r. ZSRR zalegał z opłatami tranzytowymi, mimo obniżenia przez Polskę stawek transportowych ${ }^{66}$.

Przebieg dalszych rozmów w sprawie ewakuacji i tranzytu potwierdził jednak pesymistyczne przewidywania Jerzego Makarczyka. Polska, nie mając podpisanego traktatu, nie zdołała wymusić na Rosjanach przyspieszenia ewakuacji. Kolejne rozmowy były trudne i pełne upokorzeń. Makarczykowi nie udało się odwołać gen. Dubynina, który traktował ewakuację radzieckich wojsk jako akt dobrej woli ze strony ZSRR, a nie wynik międzyrządowego porozumienia. Takie stanowisko zaprezentował 9 kwietnia 1991 r. w Bornym Sulinowie podczas oficjalnego pożegnania 20 radzieckich żołnierzy opuszczających Polskę. Makarczyk na próżno starał się, by Moskwa zdezawuowała jego twierdzenie ${ }^{67}$.

Układ o wycofaniu bojowych sił radzieckich z Polski parafowano w Moskwie 26 października 1991 r. Do 15 listopada 1992 r. miały się wycofać bojowe siły radzieckie, a jednostki tranzytowo-likwidacyjne do końca 1993 r. (zakończyła się ostatecznie 18 IX 1993 r.). W dniu 10 grudnia $1991 \mathrm{r}$. podpisano porozumienie na temat tranzytu radzieckich wojsk z Niemiec. Od 1993 r. miała przebywać w Polsce trzydziestoosobowa misja łącznikowa, jako placówka dyplomatyczna. Do ochrony tranzytu z Niemiec pozostała 2-4 tysięczna

${ }^{63}$ J. S trze l c zy k, op. cit., s. 145; Notatka informacyjna ministra spraw zagranicznych z rozmowy z ambasadorem RFN 4 II 1991r., Polska wobec zjednoczenia..., nr 87, s. 471-472.

64 J. Strzelczyk, op. cit., s. 145-146.

${ }^{65}$ J. Strzelczyk, op. cit., s. 147-148.

${ }^{66}$ J. Strzelczyk, op. cit., s. 153, 162; Zapis rozmowy K. Skubiszewskiego z H. D. Genscherem 17 VI 1991, Polska wobec zjednoczenia..., nr 97, s. 536.

${ }^{67}$ Do końca 1991 r., a więc do rozpadu ZSRR, odbyło się 13 rund rozmów, naprzemiennie w Warszawie i w Moskwie: 19-20 III, 11-12 IV, 14 V, 14 VI, 10-11 VII, 24 VII, 21-23 VIII, 26 X 199, 26-27 XI, szerzej o ich przebiegu, J. Strzelczyk, op. cit., s. 160-163, 165-166, 283, 287-288. 
grupa radzieckich żołnierzy. Polska nie ustąpiła jedynie w kwestii transportu kołowego. Ewakuacja z Polski i tranzyt z Niemiec miały się odbywać koleją ${ }^{68}$.

Debata z 25 stycznia 1991 r. stanowi przykład sposobu wyrażania opinii na temat polityki rządu przez Senat I kadencji. Jej przebieg wskazuje, że celem senatorów nie była krytyka MSZ, lecz raczej stworzenie okazji do przedyskutowania różnych aspektów problemu. Senatorowie, zdając sobie sprawę z niewielkich uprawnień w kwestiach zagranicznych, wykorzystali dostępne środki, by wspomóc działania polskiego rządu w Niemczech. Opinie, które sformułowano podczas debaty, zostały wzięte pod uwagę, przy zmianie stanowiska negocjacyjnego w kwestii ewakuacji radzieckich wojsk z Polski.

\section{Bibliografia}

Archiwalia:

Protokół posiedzenia Komisji Spraw Zagranicznych Senatu 25 I 1991, Archiwum Senatu 29/22. Dokumenty publikowane:

Polska wobec zjednoczenia Niemiec 1989-1991. Dokumenty dyplomatyczne, red. Włodzimierz Borodziej, Warszawa 2006.

Opracowania:

Cziomer Erhard, Historia Niemiec wspótczesnych 1945-2005, Warszawa 2006.

Dudek Antoni, Historia polityczna Polski 1989-2002, Warszawa 2013.

Hajnicz Artur, Ze soba czy przeciw sobie. Polska-Niemcy 1989-1992, Warszawa 1996.

Kohl Helmut, Pragnątem jedności Niemiec, Warszawa 1999.

Kukułka Józef, Historia wspótczesna stosunków międzynarodowych 1945-1994, Warszawa 1995.

Orłowski Wojciech, Senat Rzeczpospolitej Polskiej w latach 1989-1991. Geneza Instytucji, Warszawa 2009.

Strzelczyk Joanna, Ucieczka ze Wschodu. Rosja w polskiej polityce 1989-1993, Warszawa 2002.

Artykuły:

Bingen Dieter, Niemcy i Polska w nowym porzadku europejskim, „Przegląd Zachodni”, 1992, nr 2. Hailbronner Kay, Prawne aspekty zjednoczenia dwóch państw niemieckich, „Przegląd Zachodni”, 1991, $\mathrm{nr} 4$.

Rogowicz Krzysztof, Rola sejmu w wycofaniu wojsk armii radzieckiej z terytorium Polski, www. lazarski.pl/pl/pobierz/340/.

Agnieszka Małgorzata Kastory

The Problem of the Withdrawal of Soviet Troops from Germany and Poland in the Meeting of the Foreign Affairs Commission of the Senate of 25 January 1991

\section{Summary}

In January 1991, an impasse in Polish-Soviet negotiations regarding the evacuation of the Soviet army from Poland and their transit from Germany through Polish territory occurred. Therefore, on 25 January 1991, the Foreign Affairs Commission of the Senate met to hear the government's

${ }^{68}$ A. Dudek, op. cit., s. 163; K. Rogow i c z, op. cit., s. 206; J. Strzelczy k, op. cit., s. 154-155, 163, $165,287$. 
relation and decide on the role of the Senate in this crisis. The meeting was an opportunity for government members and senators to discuss the tactics of the Polish Ministry of Foreign Affairs in the negotiations with the Soviet Union and evaluate it. The discussion revealed a critical assessment of the negotiations, including the fixed date of the withdrawal of Soviet troops from Poland and making the consent to transit the troops from Germany subject to their prior evacuation from Poland. During the meeting, the Foreign Affairs Commission of the Senate decided to organise an information campaign regarding the Polish position, particularly in Germany. In the following months of 1991, Poland gradually mitigated its position in its negotiations with the USSR, increasing its flexibility in the matter of both evacuation and transit.

Key words: Foreign Affairs Commission of the Senate, soviet army, evacuation, transit, Poland, Germany, USSR 